\title{
Diversity, Morphology and Comparative Study of Season of Airborne Pollen Grains Abundance in Four Local Government Areas in Akoko Division, Ondo State, Nigeria
}

\author{
Essien Benjamin Christopher* and Ige Olugbenga Ebenezer \\ Department of Plant Science and Biotechnology, Adekunle Ajasin University, Akungba-Akoko, Ondo State, Nigeria

\section{*Corresponding Author} \\ Essien Benjamin Christopher
}

\author{
Article History \\ Received: 07.07.2019 \\ Accepted: 22.07 .2019 \\ Published: 30.07 .2019
}

\begin{abstract}
The study of atmospheric pollen content of an area is useful in providing vital information on environmental change, vegetation type, species composition and their utilization for safety health and sustainable development. The current study examined the diversity, morphology and comparative study of airborne pollen grains from four Local Government Areas in Akoko division, Ondo State, Nigeria. This study was carried out in fourty randomly selected locations to examine the temporal and spatial relationship between the atmospheric pollen content and its vegetation. The airborne pollen grains were collected with Modified Tauber Sampler using simple random sampling technique and analyzed palynologically. Results showed 50,661 pollen grains comprising of 182 pollen types belonging to 74 angiospermic plant families were encountered. Three (3) of these pollen types were identified to family level, 57 to species level, 121 to generic level and one (1) unidentified. The predominant pollen types belong to the family Poaceae, Elaeis guineensis, Alchornea cordifolia, Aspilia africana, Casuarina equisetifolia, and Tridax procumbens. The presence of Empetrum nigrum, Linnea borealis, Linum sp., Stereospermum kunthianum and Vitellaria paradoxa pollen indicates evidence of long distance transport. Airborne pollen grains were most abundant between September and January. Rainfall and relative humidity had more negative effect on pollen concentration. The effects of temperature and light intensity varied considerably with time and location because their effects are influenced by other meteorological factors. Continuous environmental monitoring through pollen rain analysis is recommended in order to produce a pollen calendar for the studied area.
\end{abstract}

Keywords: Airborne-pollen; Season of abundance; Diversity; Pollen morphology

\section{INTRODUCTION}

Airborne pollen grains, which are atmospheric particles of biogenic origin, is a common cause of allergy-related diseases such as asthma, bronchitis, rhinitis, and upper respiratory tract infection [1,2]. The study of pollen grains of plant species reveals great diversity in their sizes, shapes, sculpture, density and abundance among other attributes [3].

Pollen identification, the basis of palynology, is based exclusively on pollen morphology [4, 5]. Pollen morphology is also important in understanding the functional aspects of pollen such as pollination biology and pollen- pistil interaction [5]. Pollen morphology is of great significance in taxonomy, phylogeny, palaeobotany, aeropalynology and pollen allergy $[1,6]$. Pollen grains and spores are part of the life cycles of the plant and in particular, lend themselves to these applications because they are the most abundant biological parameter consistently present in the air masses. Since they are direct products of plants, their abundance and distribution respond naturally to the environmental factor affecting their parent sources [7].

The release, distribution and sedimentation of these airborne pollen grains are influenced by a number of factors such as the type and floristic composition of the vegetation which determine the abundance and types of pollen that are released into the atmosphere [8-10]. Also, the flowering pattern of individual plants play important role in determining the abundance and taxa of pollen circulating in the atmosphere [11]. Airborne pollen grains generally travel short distances; however, when they are blown into the upper strata of the atmosphere, pollen grains travel long distances, before they are deposited [12]. Meteorological factors, in particular temperature, precipitation, humidity and wind speed strongly influence airborne pollen counts [13, 7]. Pollen dispersal is facilitated by

Copyright @ 2019: This is an open-access article distributed under the terms of the Creative Commons Attribution license which permits unrestricted use, distribution, and reproduction in any medium for non commercial use (NonCommercial, or CC-BY-NC) provided the original author and source are credited. 
dry weather and high wind velocity. Pollen count is reduced after precipitation. The widely dispersed pollen and spores provide a broad picture of the surrounding vegetation of the areas in which they are produced. Even though sometimes, some of them are blown into these areas from distant places, experienced palynologists are most of the time able to detect these re-deposited pollen and spores by differences in preservation (e.g. colour, corrosion, wear), ecological or stratigraphical inconsistencies and other associated evidences of being re-deposited [14].

Some factors that aid in the dispersal are the size, shape and density of the pollen and spores, the position of the parent plants (that produce them) in the vegetation and the prevailing climatic conditions [15]. The distinctive surface sculptures of pollen grains aid in the identification of their parent plants to at least family level [16]. Their other qualities such as small size, abundance and high resistance to degradation have made them an invaluable evidence of vegetation as well as environmental changes [17]. Because of the transitional location of Akoko division, Ondo State, Nigeria between the tropical rainforest in the South and the true savanna in the North; the area receives particles moving from the South to the Northern part of Nigeria and vice versa. Equally, the movements of the South-West Monsoon and North-East Trade winds across the latitudinal zones of Nigeria carrying along with them large quantities of particles which are deposited along their routes depending on the strength of the winds during the major seasons of the year. The aim of this study is to determine the taxa of airborne pollen grains circulating in the study area and to ascertain the pattern of seasonal variation in the distribution of the prevalent pollen types.

\section{MATERIALS AND METHODS}

Fourty locations were randomly selected within the four Local Government Areas of Akoko division, Ondo State, Nigeria as sampling sites. The sampling sites for the study was purposely selected to reflect (represent) as far as possible the Local Government Area of the study. In choosing the sites, consideration was also given to urbanization, accessibility, and safety of the sampling (experimental materials) instruments among others [18].

At each site, a pollen trap (Modified Tauber Sampler) was mounted according to the methods of Tauber [19, 20], Pardoe et al. [21] and Giesecke et al. [22]. Prior to this, a mixture of glycerol $(65 \mathrm{ml})$, formalin $(30 \mathrm{ml})$ and phenol $(5 \mathrm{ml})$ was poured into each of the trap. The positions of the traps at various locations were recorded using a Global Position System (GPS). The solutions in the trap prevented the palynomorphs from drying up, kill insects and also prevented the decay of dead organisms. The trap was left to stand throughout the duration of the study period. Fortnightly of each month, solution collection was done. The traps were washed with water to remove any contaminants and were then recharged with the above mentioned chemical solution. This procedure was repeated bi-monthly from October 2016 to December 2017 (dry season and rainy seasons' samples) for one year. The palynomorphs were recovered through centrifugation at 2000 r.p.m (revolution per minute) for 5 minutes and supernatant decanted each time. The precipitates were washed twice with distilled water and recovered through centrifugation. The sediments were treated with glacial acetic acid to remove water before acetolysis $[23,24]$. The recovered precipitates were washed with glacial acetic acid, and finally washed twice with distilled water, centrifuged each time and decanted. The recovered palynomorphs were stored in a plastic vials in glycerin and ethanol solution (2:1).

The palynomorphs were analysed palynologically and microscopically with Olympus microscope at x400 magnification for counting and Leica microscope at x1000 magnification for detailed morphological studies. Palynomorphs identification, counting and classification were done with the help of reference descriptions and photomicrographs from Agwu and Akanbi [24], Bonnefille and Riollet [25], Sowunmi [26] and Shubharani et al. [4]. In addition, prepared slides of pollen samples in the Palynological Research Unit; Department of Plant Science and Biotechnology, Adekunle Ajasin University, Akungba- Akoko, Nigeria were used.

\section{RESULTS AND DISCUSSIONS}

A total of 182 pollen types were identified across the study locations. These pollen types belong to 74 angiospermic plant families, 1 gymnosperms and 4 pteridophytes (Table 1). Out of these 74 plant families encountered, 66 families belong to the dicotyledonous plants, 6 to monocotyledonous plants, 1 to the gymnospermous plants and 1 was unidentified (Indeterminata).

However, the cumulative monthly pollen record showed that a total of 50661 pollen grains were recorded with the highest monthly pollen counts of 9,023 recorded in November, followed by December $(8,750)$, October $(5,789)$, September $(5,600)$ and the least recorded in August $(1,926)$ and July $(1,530)$ respectively (Table 1).

Statistical analysis of the mean monthly pollen counts showed that there was a significant difference $(P<0.05)$ in the monthly pollen abundance. The multiple comparison using DMRT showed that the quantity of pollen counts recorded in November was significantly different $(P<0.05)$ from those recorded in the months of March, April, May, June, July, August, September, October, January and February, but not significantly different from the pollen counts recorded in December. There was no significant difference between the quantity of pollen recorded in December and other months (Table 4). Equally, statistical analysis of pollen record at the study locations showed that there was significant difference $(P<0.05)$ between the abundance of pollen grains recorded at the study locations (Table 5). Photomicrographs of some selected palynomorphs are shown in Figure 3. 
The study also showed that the airborne pollen grains were unevenly distributed throughout the year with many sporadically dispersed monthly and at the study locations. Similar findings were reported by $[12,13,16]$.

Table-1: Pollen grains and fern spore spectra classified to family level for the study period (October 2016- September 2017)

\begin{tabular}{|c|c|c|c|c|c|c|c|c|c|c|c|c|c|c|}
\hline $\mathrm{S} / \mathrm{N}$ & Plant Family & OCT. & NOV. & DEC. & JAN. & FEB. & MAR & APR. & MAY & JUN. & JUL. & AUG. & SEP. & TOTAL \\
\hline 1 & Acanthaceae & 4 & 13 & 0 & 3 & 0 & 4 & 1 & 8 & 6 & 2 & 2 & 5 & 48 \\
\hline 2 & $\begin{array}{l}\text { Amaranthaceae/ } \\
\text { Chenopodiaceae }\end{array}$ & 26 & 28 & 24 & 16 & 11 & 158 & 35 & 53 & 26 & 9 & 3 & 26 & 415 \\
\hline 3 & Anacardiceae & 1 & 129 & 236 & 4 & 0 & 92 & 192 & 87 & 2 & 35 & 51 & 197 & 1026 \\
\hline 4 & Annonaceae & 1 & 0 & 2 & 3 & 0 & 3 & 15 & 0 & 0 & 8 & 3 & 0 & 35 \\
\hline 5 & Apocynaceae & 3 & 283 & 0 & 224 & 26 & 20 & 8 & 8 & 2 & 2 & 0 & 7 & 583 \\
\hline 6 & Arecaceae & 350 & 1411 & 1153 & 400 & 258 & 639 & 600 & 330 & 148 & 123 & 187 & 379 & 5978 \\
\hline 7 & Asteraceae & 678 & 955 & 66 & 155 & 38 & 15 & 41 & 80 & 583 & 85 & 208 & 152 & 3056 \\
\hline 8 & Bignoniaceae & 3 & 41 & 41 & 25 & 0 & 41 & 0 & 13 & 8 & 11 & 0 & 8 & 191 \\
\hline 9 & Bombacaceae & 25 & 14 & 6 & 5 & 4 & 2 & 19 & 18 & 13 & 0 & 3 & 17 & 126 \\
\hline 10 & Boraginaceae & 0 & 0 & 0 & 0 & 0 & 0 & 0 & 3 & 0 & 0 & 0 & 0 & 3 \\
\hline 11 & Burseraceae & 1 & 12 & 10 & 0 & 0 & 7 & 22 & 38 & 7 & 0 & 0 & 1 & 98 \\
\hline 12 & Caesalpinoideae & 117 & 143 & 133 & 91 & 76 & 52 & 91 & 49 & 19 & 30 & 92 & 247 & 1140 \\
\hline 13 & Cannabaceae & 0 & 0 & 0 & 15 & 0 & 7 & 3 & 1 & 0 & 0 & 2 & 1 & 29 \\
\hline 14 & Capparaceae & 1 & 0 & 4 & 0 & 0 & 0 & 9 & 1 & 0 & 0 & 0 & 0 & 15 \\
\hline 15 & Caprifoliaceae & 3 & 5 & 2 & 2 & 0 & 0 & 0 & 0 & 0 & 5 & 2 & 0 & 19 \\
\hline 16 & Caricaceae & 0 & 0 & 0 & 0 & 0 & 0 & 0 & 0 & 0 & 0 & 11 & 31 & 42 \\
\hline 17 & Casuarinaceae & 719 & 14 & 23 & 27 & 17 & 61 & 31 & 110 & 34 & 33 & 90 & 33 & 1192 \\
\hline 18 & Celastraceae & 0 & 0 & 0 & 4 & 9 & 0 & 0 & 0 & 0 & 0 & 0 & 0 & 13 \\
\hline 19 & Chrysobalanaceae & 0 & 0 & 0 & 0 & 0 & 31 & 5 & 11 & 9 & 0 & 0 & 0 & 56 \\
\hline 20 & Clusiaceae & 4 & 2 & 5 & 0 & 0 & 8 & 15 & 5 & 25 & 29 & 0 & 2 & 95 \\
\hline 21 & Cochlospermaceae & 0 & 0 & 0 & 0 & 0 & 5 & 0 & 0 & 30 & 1 & 0 & 0 & 36 \\
\hline 22 & Colchicaceae & 0 & 0 & 0 & 0 & 0 & 5 & 7 & 4 & 2 & 0 & 3 & 0 & 21 \\
\hline 23 & Combretaceae & 11 & 42 & 30 & 24 & 47 & 40 & 31 & 42 & 42 & 12 & 20 & 35 & 376 \\
\hline 24 & Commelinaceae & 0 & 0 & 0 & 0 & 0 & 3 & 7 & 0 & 0 & 0 & 0 & 0 & 10 \\
\hline 25 & Connaraceae & 0 & 0 & 0 & 0 & 0 & 4 & 1 & 11 & 0 & 0 & 0 & 0 & 16 \\
\hline 26 & Convolvulaceae & 0 & 6 & 0 & 0 & 6 & 7 & 0 & 0 & 12 & 0 & 0 & 4 & 35 \\
\hline 27 & Costaceae & 0 & 2 & 0 & 1 & 0 & 0 & 0 & 3 & 2 & 5 & 0 & 0 & 13 \\
\hline 28 & Cucurbitaceae & 0 & 0 & 0 & 0 & 0 & 4 & 12 & 3 & 0 & 0 & 0 & 5 & 24 \\
\hline 29 & Cyperaceae & 19 & 13 & 12 & 10 & 9 & 17 & 10 & 116 & 42 & 25 & 22 & 26 & 321 \\
\hline 30 & Dichapetalaceae & 0 & 0 & 0 & 0 & 0 & 0 & 0 & 2 & 3 & 0 & 0 & 0 & 5 \\
\hline 31 & Dilleniaceae & 0 & 3 & 0 & 0 & 0 & 1 & 2 & 4 & 0 & 0 & 0 & 0 & 10 \\
\hline 32 & Dioscoreaceae & 0 & 0 & 0 & 0 & 0 & 8 & 3 & 1 & 0 & 0 & 0 & 2 & 14 \\
\hline 33 & Diptilomiodeae & 0 & 0 & 0 & 0 & 0 & 6 & 9 & 0 & 0 & 0 & 0 & 0 & 15 \\
\hline 34 & Ebanaceae & 0 & 0 & 0 & 0 & 0 & 0 & 3 & 6 & 18 & 88 & 237 & 0 & 352 \\
\hline 35 & Euphorbiaceae & 25 & 518 & 851 & 200 & 104 & 229 & 140 & 148 & 67 & 9 & 16 & 68 & 2375 \\
\hline 36 & Fagaceae & 0 & 4 & 1 & 7 & 0 & 0 & 0 & 0 & 0 & 0 & 0 & 0 & 12 \\
\hline 37 & Gentianaceae & 0 & 1 & 2 & 3 & 0 & 0 & 0 & 0 & 2 & 2 & 0 & 0 & 10 \\
\hline 38 & Hypericaceae & 35 & 0 & 0 & 2 & 8 & 5 & 21 & 20 & 25 & 27 & 31 & 0 & 174 \\
\hline 39 & Irvingiaceae & - & 7 & 4 & 123 & 15 & 202 & 29 & 31 & 2 & 3 & 3 & 7 & 426 \\
\hline 40 & Lamiaceae & 113 & 56 & 91 & 28 & 31 & 27 & 9 & 12 & 35 & 59 & 34 & 267 & 762 \\
\hline 41 & Leeaceae & 0 & 3 & 0 & 0 & 0 & 0 & 0 & 0 & 2 & 0 & 0 & 0 & 5 \\
\hline 42 & Linaceae & 12 & 0 & 0 & 3 & 5 & 8 & 6 & 12 & 12 & 23 & 8 & 0 & 89 \\
\hline 43 & Loganiaceae & 5 & 0 & 18 & 3 & 3 & 2 & 2 & 5 & 2 & 1 & 0 & 2 & 43 \\
\hline 44 & Malvaceae & 35 & 311 & 60 & 49 & 164 & 8 & 9 & 3 & 19 & 1 & 34 & 30 & 723 \\
\hline 45 & Melastomataceae & 41 & 0 & 0 & 0 & 0 & 0 & 0 & 0 & 11 & 26 & 21 & 13 & 112 \\
\hline$\frac{76}{46}$ & Meliaceae & 4 & 22 & 21 & 10 & 7 & 31 & 76 & 10 & 8 & 13 & 17 & 7 & 226 \\
\hline 47 & Mimosoideae & 91 & 342 & 390 & 458 & 372 & 177 & 182 & 277 & 79 & 63 & 29 & 94 & 2554 \\
\hline 48 & Moraceae & 0 & 50 & 143 & 161 & 0 & 277 & 17 & 12 & 5 & 0 & 0 & 19 & 684 \\
\hline 49 & Myristicaceae & 0 & 61 & 21 & 32 & 0 & 0 & 0 & 0 & 0 & 0 & 0 & 10 & 124 \\
\hline 50 & Myrtaceae & 80 & 72 & 3 & 9 & 5 & 49 & 49 & 253 & 28 & 17 & 60 & 30 & 655 \\
\hline 51 & Ochnaceae & 4 & 9 & 41 & 6 & 10 & 15 & 14 & 14 & 2 & 0 & 4 & 4 & 123 \\
\hline 52 & Olacaceae & 2 & 0 & 5 & 7 & 7 & 2 & 0 & 0 & 0 & 0 & 2 & 4 & 29 \\
\hline 53 & Pandaceae & 1 & 5 & 13 & 11 & 0 & 36 & 21 & 10 & 0 & 0 & 1 & 2 & 100 \\
\hline 54 & Papilionoideae & 11 & 15 & 16 & 0 & 3 & 29 & 19 & 12 & 13 & 0 & 0 & $\frac{2}{6}$ & 124 \\
\hline 55 & Passifloraceae & 0 & 0 & 0 & 0 & 0 & 0 & 1 & $\frac{12}{4}$ & $\frac{10}{2}$ & 0 & 0 & 0 & 7 \\
\hline 56 & Pedaliaceae & 0 & 72 & 15 & 15 & 0 & 0 & 0 & 0 & 0 & 0 & 0 & 125 & 227 \\
\hline 57 & Phyllanthaceae & 44 & 61 & 435 & 122 & 41 & 60 & 69 & 247 & 59 & 28 & 28 & 36 & 1230 \\
\hline 58 & Pinaceae & 9 & 0 & 7 & 4 & 0 & 1 & 4 & 4 & 1 & 2 & 5 & 2 & 39 \\
\hline 59 & Plumbaginaceae & 11 & 0 & 0 & 0 & 0 & 0 & 0 & 0 & 0 & 0 & 3 & 7 & 21 \\
\hline 60 & Poaceae & 3109 & 3892 & 4145 & 1679 & 594 & 551 & 567 & 889 & 699 & 703 & 565 & 3418 & 20811 \\
\hline 61 & Polygalaceae & 5 & 21 & 15 & 18 & 0 & 0 & 0 & 0 & 0 & 0 & 8 & 10 & 77 \\
\hline 62 & Portulacaceae & 18 & 12 & 8 & 0 & 0 & 0 & 0 & 0 & 0 & 0 & 5 & 5 & 48 \\
\hline 63 & Proteaceae & 1 & 1 & 0 & 3 & 3 & 0 & 0 & 0 & 0 & 0 & 1 & 0 & 9 \\
\hline 64 & Rhamnaceae & 0 & 1 & 2 & 1 & 0 & 9 & 7 & 0 & 0 & 0 & 0 & 0 & 20 \\
\hline 65 & Rosaceae & 7 & 11 & 3 & 8 & 0 & 48 & 22 & 159 & 12 & 4 & 12 & 14 & 300 \\
\hline 66 & Rubiaceae & 73 & 171 & 162 & 193 & 5 & 269 & 37 & 106 & 21 & 13 & 48 & 45 & 1143 \\
\hline 67 & Rutaceae & 4 & 9 & 41 & 6 & 10 & 15 & 14 & 14 & 2 & 0 & 4 & 4 & 123 \\
\hline 68 & Sapindaceae & $\frac{4}{2}$ & 0 & 5 & 7 & 7 & 2 & 16 & 47 & 24 & 0 & 4 & 4 & 116 \\
\hline 69 & Sapotaceae & 1 & 11 & 5 & 7 & 0 & 27 & 18 & 10 & 0 & 0 & \begin{tabular}{|l}
2 \\
1
\end{tabular} & 2 & 82 \\
\hline 70 & Solanaceae & 28 & 4 & 406 & 4 & 2 & 10 & 12 & 4 & 33 & 6 & 5 & 16 & 530 \\
\hline 71 & Sterculiaceae & 16 & 129 & 44 & 133 & 39 & 50 & 57 & 243 & 26 & 22 & 23 & 145 & 927 \\
\hline 72 & Urticaceae & 26 & 25 & 20 & 18 & 0 & 0 & 0 & 0 & 0 & 0 & \begin{tabular}{|l|l|}
14 \\
\end{tabular} & 19 & 122 \\
\hline 73 & Verbenaceae & 9 & 9 & 3 & 3 & 3 & 0 & 0 & 0 & 0 & 0 & 3 & 3 & 33 \\
\hline \multirow[t]{2}{*}{74} & Indeterminata & 1 & 2 & 7 & 1 & 6 & 1 & 4 & 4 & 1 & 5 & \begin{tabular}{|c|}
3 \\
\end{tabular} & 4 & 39 \\
\hline & SUB TOTAL & 5789 & 9023 & 8750 & 4343 & 1945 & 3380 & 2594 & 3557 & 2225 & 1530 & 1926 & 5600 & 50661 \\
\hline 1 & Aspidiaceace & 0 & 0 & 0 & 0 & 0 & 0 & 22 & 0 & 0 & 2 & 4 & 0 & 28 \\
\hline 2 & Davalliaceae & 0 & 0 & 0 & 0 & 0 & 0 & 11 & 31 & 0 & $\frac{2}{0}$ & 0 & 0 & 42 \\
\hline 3 & Hymenophyllaceae & 0 & 0 & 0 & 0 & 0 & 0 & 2 & 3 & 0 & 0 & 0 & 0 & 5 \\
\hline 4 & Pteridaceae & 127 & 25 & 114 & 22 & 19 & 22 & 40 & 49 & 54 & 23 & 22 & 422 & 939 \\
\hline & SUB TOTAL & 127 & 25 & 114 & 22 & 19 & 22 & 75 & 83 & 54 & 25 & \begin{tabular}{|l|}
26 \\
\end{tabular} & 422 & 1014 \\
\hline & GRAND TOTAL & 5916 & 9375 & 8537 & 4365 & 1964 & 3402 & 2669 & 3640 & 2279 & 1555 & 1952 & 6022 & 51675 \\
\hline
\end{tabular}




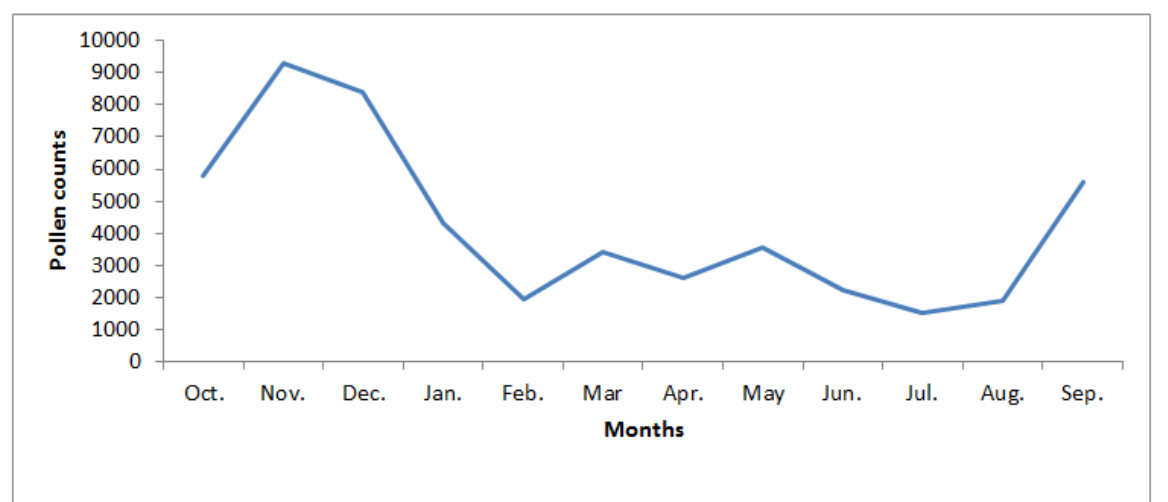

Fig-1: Variation in cumulative monthly pollen counts recorded during the study period

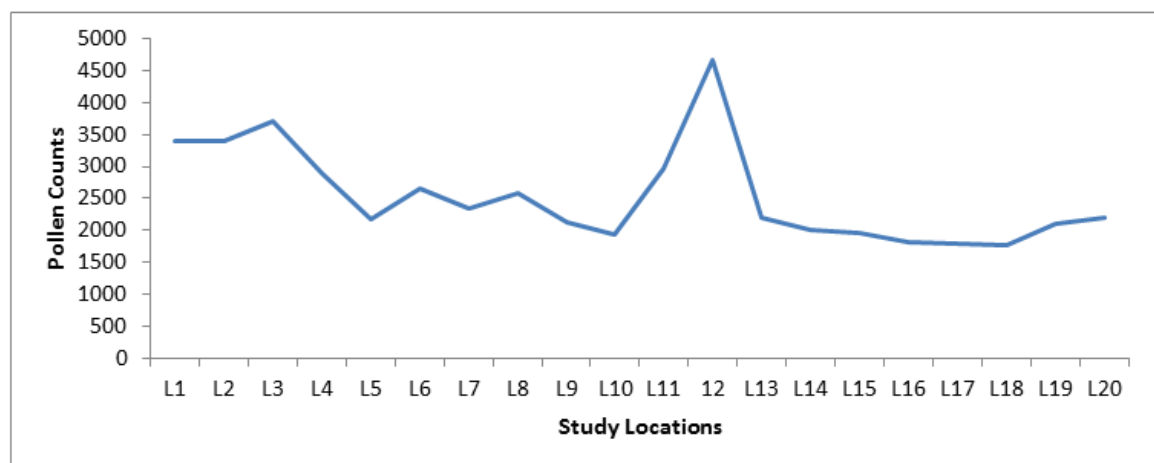

Fig-2: Variation in cumulative pollen counts recorded across the study locations

LEGEND: L1=Ifira, L2=Ipe, L3=Ipesi, L4=Isua, L5=Sosan, L6=Akunnu, L7=Auga, L8=lboropa, L9=Ikare, 10=Ise, L11=Akungba, L12=Ayegunle, L13=Oba, L14=OkeOka, L15=Supare, L16=Arigidi, L17=Ogbagi, L18=Oke-Agbe, L19=Ikaram, L20=Irun.

Among the classified plant families, the maximum mean number of pollen counts of $86.71 \pm 5.74$ was recorded for Poaceae followed by $(8.29 \pm 0.66)$ Arecaceae, $(4.97 \pm 0.99)$ Casuarinaceae and $(2.12 \pm 0.29)$ Asteraceae and the least by $(0.02 \pm 0.01)$ Proteaceae, $(0.02 \pm 0.01)$ Hymenophyllaceae as well as $(0.01 \pm 0.01)$ Boraginaceae and $(0.01 \pm 0.01)$ Pteridaceae. Of the individual plant species Elaeis guineensis contributed the maximum mean number of pollen counts $(24.65 \pm 1.52)$ followed by $(9.25 \pm 1.21)$ Alchornea cordifolia, (5.19 \pm 1.06$)$ Aspilia africana, (4.97 \pm 0.99$)$ Casuarina equisetifolia, (4.55 \pm 1.26$)$ Tridax procumbens, $(4.06 \pm 0.55)$ Lannea acida and the least by $(0.01 \pm 0.01)$ Heliotropium sp., $(0.01 \pm 0.01)$ Capparis sp., $(0.01 \pm 0.01)$ Protea madiensis, $(0.01 \pm 0.01)$ Tectona grandis and $(0.00 \pm 0.00)$ Anopteris hexagona .

With respect to the monthly pollen abundance in the atmosphere, the results showed that the concentration of pollen grains in the atmosphere fluctuates considerably with the seasons. The monthly airborne pollen concentrations showed three discernible periods of pollen variability in the atmosphere; (1) February - June (dry season to early rainy season); (2) July - August (mid rainy season) and (3) September - January (late rainy season to early dry season) (Fig. 1). The three periods of pollen abundance in the atmosphere showed that the highest mean concentration occurred during the late rainy season to early dry season, followed by the period of dry season to early rainy season and the least occurred during the mid-rainy season (Table 2).

Table-2: Seasonal Pollen Abundance in Akoko Environment

\begin{tabular}{|l|l|l|l|l|}
\hline S/N & Seasons & Months & Absolute counts & Mean \\
\hline 1 & Late rainy season to early dry season & September to January & 33,444 & 6688.8 \\
\hline 2 & Dry season to early rainy season & February to June & 13,761 & 2752.2 \\
\hline 3 & Mid rainy season & July to August & 3,456 & 1728.0 \\
\hline 4 & Cumulative total pollen counts & & 50,661 & \\
\hline
\end{tabular}

There were noticeable monthly increase and decrease in the quantity of pollen grains and other palynomorphs counted. The pollen load of the entire study area varied quantitatively and qualitatively not only from month-to-month but also from location-tolocation (Table 3). At the study locations, the highest pollen counts was recorded in Ayegunle $(4,665)$ followed by Ipesi $(3,710)$, Ifira $(3,404)$, Ipe $(3,389)$, and in Akungba $(2,955)$ while the least were in Ogbagi $(1,790)$ and Oke- Agbe $(1,763)($ Table 3$)$. The analysis of variance showed that there was significant difference in the mean pollen counts recorded across the study locations. Multiple comparisons using Duncan Multiple Range Test (DMRT) showed that the highest mean pollen counts was recorded in Ayegunle $\left(2.07 \pm 0.45^{d}\right)$ and was significantly different from those recorded for all other study locations except Ipesi, Ifira and Ipe (Table 5). Findings corroborated favourably with the report of Latorre and Belmonte [27]. 
Table-3: Summary of the Pollen types identified at the study locations

\begin{tabular}{|c|c|c|c|c|c|c|c|c|}
\hline $\mathrm{S} / \mathrm{N}$ & $\begin{array}{l}\text { Study } \\
\text { Locations } \\
\text { (L1-L20) }\end{array}$ & $\begin{array}{l}\text { Total No. of } \\
\text { pollen types } \\
\text { counted }\end{array}$ & $\begin{array}{l}\text { Total No. of } \\
\text { pollen } \\
\text { counted }\end{array}$ & $\begin{array}{l}\text { Total No. of } \\
\text { Plant } \\
\text { Families }\end{array}$ & $\begin{array}{l}\text { Total No. } \\
\text { classified to } \\
\text { Family level }\end{array}$ & $\begin{array}{l}\text { Total No. } \\
\text { classified to } \\
\text { Generic level }\end{array}$ & $\begin{array}{l}\text { Total No. } \\
\text { classified to } \\
\text { Species level }\end{array}$ & $\begin{array}{l}\text { Total No. of Plant } \\
\text { family Unidentified }\end{array}$ \\
\hline 1 & Ifira & 125 & 3404 & 59 & 3 & 81 & 40 & 1 \\
\hline 2 & Ipe & 110 & 3389 & 55 & 3 & 80 & 27 & 0 \\
\hline 3 & Ipesi & 108 & 3710 & 53 & 3 & 76 & 28 & 1 \\
\hline 4 & Isua & 91 & 2895 & 54 & 3 & 63 & 24 & 1 \\
\hline 5 & Sosan & 80 & 2180 & 45 & 3 & 58 & 18 & 1 \\
\hline 6 & Akunnu & 106 & 2664 & 58 & 3 & 70 & 32 & 1 \\
\hline 7 & Auga & 110 & 2338 & 54 & 3 & 76 & 30 & 1 \\
\hline 8 & Iboropa & 96 & 2587 & 53 & 3 & 66 & 26 & 1 \\
\hline 9 & Ikare & 86 & 2130 & 51 & 3 & 61 & 21 & 1 \\
\hline 10 & Ise & 75 & 1923 & 43 & 3 & 51 & 20 & 1 \\
\hline 11 & Akungba & 78 & 2955 & 50 & 3 & 51 & 23 & 1 \\
\hline 12 & Ayegunle & 89 & 4665 & 50 & 3 & 61 & 24 & 1 \\
\hline 13 & Oba & 81 & 2187 & 47 & 3 & 56 & 21 & 1 \\
\hline 14 & Oke-Oka & 81 & 2008 & 43 & 2 & 57 & 21 & 1 \\
\hline 15 & Supare & 73 & 1955 & 43 & 2 & 49 & 21 & 1 \\
\hline 16 & Arigidi & 71 & 1821 & 42 & 3 & 53 & 15 & 0 \\
\hline 17 & Ogbagi & 66 & 1790 & 38 & 3 & 44 & 18 & 1 \\
\hline 18 & Oke-Agbe & 64 & 1763 & 42 & 3 & 46 & 14 & 1 \\
\hline 19 & Ikaram & 67 & 2111 & 42 & 3 & 51 & 12 & 1 \\
\hline \multirow[t]{2}{*}{20} & Irun & 78 & 2186 & 43 & 3 & 56 & 19 & 0 \\
\hline & TOTAL & 1735 & 50661 & 965 & 58 & 1206 & 454 & 17 \\
\hline
\end{tabular}

Table-4: Mean monthly pollen counts recorded during the study period

\begin{tabular}{|l|l|l|}
\hline S.L No & Month & Mean Pollen grains \pm S.E \\
\hline 1 & October & $1.55 \pm 0.21^{\mathrm{d}}$ \\
\hline 2 & November & $2.46 \pm 0.27^{\mathrm{e}}$ \\
\hline 3 & December & $2.23 \pm 0.28^{\mathrm{e}}$ \\
\hline 4 & January & $1.18 \pm 0.12^{\mathrm{cd}}$ \\
\hline 5 & February & $0.52 \pm 0.05^{\mathrm{ab}}$ \\
\hline 6 & March & $0.89 \pm 0.08^{\mathrm{abc}}$ \\
\hline 7 & April & $0.70 \pm 0.07^{\mathrm{abc}}$ \\
\hline 8 & May & $0.96 \pm 0.14^{\mathrm{bc}}$ \\
\hline 9 & June & $0.59 \pm 0.12^{\mathrm{ab}}$ \\
\hline 10 & July & $0.42 \pm 0.09^{\mathrm{a}}$ \\
\hline 11 & August & $0.51 \pm 0.07^{\mathrm{ab}}$ \\
\hline 12 & September & $1.48 \pm 0.24^{\mathrm{d}}$ \\
\hline 13 & p Value & $0.000^{*}$ \\
\hline
\end{tabular}

Means not followed by the same letter are significantly different at $\mathrm{P}<0.05$ (DMRT). *-significant at $p<0.05$

Table-5: Mean pollen grains recorded at the study locations

\begin{tabular}{|l|l|}
\hline Study Location & Mean Pollen grains \pm S.E \\
\hline Ayegunle & $2.07 \pm 0.45^{\mathrm{d}}$ \\
\hline Ipesi & $1.64 \pm 0.25^{\mathrm{cd}}$ \\
\hline Ipe & $1.54 \pm 0.27^{\mathrm{bcd}}$ \\
\hline Ifira & $1.51 \pm 0.21^{\mathrm{abcd}}$ \\
\hline Akungba & $1.31 \pm 0.25^{\mathrm{abc}}$ \\
\hline Isua & $1.28 \pm 0.20^{\mathrm{abc}}$ \\
\hline Akunnu & $1.19 \pm 0.18^{\mathrm{abc}}$ \\
\hline Iboropa & $1.14 \pm 0.19^{\mathrm{abc}}$ \\
\hline Auga & $1.05 \pm 0.17^{\mathrm{abc}}$ \\
\hline Oba & $0.97 \pm 0.19^{\mathrm{abc}}$ \\
\hline Irun & $0.97 \pm 0.19^{\mathrm{abc}}$ \\
\hline Sosan & $0.97 \pm 0.17^{\mathrm{abc}}$ \\
\hline Ikare & $0.94 \pm 0.18^{\mathrm{abc}}$ \\
\hline Ikaram & $0.94 \pm 0.17^{\mathrm{abc}}$ \\
\hline Oke-Oka & $0.89 \pm 0.18^{\mathrm{ab}}$ \\
\hline Ise & $0.86 \pm 0.17^{\mathrm{ab}}$ \\
\hline Supare & $0.86 \pm 0.16^{\mathrm{ab}}$ \\
\hline Arigidi & $0.80 \pm 0.15^{\mathrm{a}}$ \\
\hline Ogbagi & $0.79 \pm 0.18^{\mathrm{a}}$ \\
\hline Oke-Agbe & $0.78 \pm 0.15 \mathrm{a}$ \\
\hline p Value & $0.000^{*}$ \\
\hline
\end{tabular}

Means not followed by the same letter are significantly different at $P<0.05$ (DMRT). *-significant at $p<0.05$. 
The study also showed that the airborne pollen grains were unevenly distributed throughout the year with many sporadically dispersed monthly and at the study locations. Among the classified plant families, the maximum mean number of pollen counts of $86.71 \pm 5.74$ was recorded for Poaceae followed by $(8.29 \pm 0.66)$ Arecaceae, $(4.97 \pm 0.99)$ Casuarinaceae and $(2.12 \pm 0.29)$ Asteraceae and the least by $(0.02 \pm 0.01)$ Proteaceae, $(0.02 \pm 0.01)$ Hymenophyllaceae as well as $(0.01 \pm 0.01)$ Boraginaceae and $(0.01 \pm 0.01)$ Pteridaceae.

The abundance in monthly pollen concentration is also reflected in Figures 4 to 10. Among the major pollen contributing plants are Elaeis guineensis, Alchornea cordifolia, Aspilia africana, Casuarina equisetifolia, Tridax procumbens, Lannea acida, and those of the family Poaceae. The monthly abundance of their pollen is shown in Figures 4 and 5 . Among the moderate pollen contributing plants are those of Triplochiton scleroxylon, Parkia biglobosa, Milicia excelsa, Senna occidentale, Prosopis africana, Gutenbergia sp., Sida acuta, Periploca sp., Albizia zygia, Solanum melongena, Hymenocardia acida, Irvingia gabonensis, Hyptis suaveolens, Combretum sp., and Nauclea latifolia (Sarcocephalus latifolius) among others.

With regards to the different species or families, Poaceae which is among the predominanat plant communities (including cultivated species) in the study area produces large quantities of pollen grains which are release into the atmosphere. The monthly pollen abundance of Poaceae showed that the frequency increased greatly from September, reached its peak in November and thereafter declined progressively to a relatively low level from February (Figure 4i). The pollen of Elaeis guineensis declined progressively from its second peak in March to July, after which it increased again reaching its peak in December. It subsequently declined from November to February (Figure 4ii). Alchornea cordifolia pollen also declined from its second peak in March to very low levels from July to September. From October the pollen abundance increased sharply and reached its highest peak in December and declined again from January to February (Figure 4iii).

Equally, the pollen abundance of of Amaranthaceae/ Chenopodiaceae increased sharply to its highest peak in March and declined sharply in April. From May, the pollen abundance declined again progressively up to August, and rose again in September, maintaining a relatively stable presence up to December before declining again to the lowest level in February (Figure 6ix) whereas Periploca sp., Aspilia africana, and Tridax procumbens pollen only showed a major peak of abundance in November (Figures 6x, 5vi and 4iv). For Lannea acida the pollen abundance showed three peaks of highest occurrence in the months of April, September and December (Figure 5vii), while those of Combretum sp. fluctuated considerably from February to June having high occurrences in February, May, June, and September to October (Figure 6xi). Although the pollen of Triplochiton scleroxylon was not relatively abundant in the atmosphere, the output was still high in May and September despite the fact that it was a time of heavy rainfall (Figure 9xxiii). Hyptis suaveolens, a farmland and roadside weed had its peak of pollen abundance in August, while Nauclea latifolia (Sarcocephalus latifolius) pollen increased considerably in March reaching its peak in May and declined between June and July (Figure 9xxi). The pollen of Irvingia gabonensis (an economic tree) had its major peak of abundance in May, and declined to a very low level from June to December and increased slightly in January (Figure 7xiii). That of Parkia biglobosa increased to its first peak of abundance in December and thereafter declined progressively up to March before rising to its second peak in May (Figure 8xvi), while the pollen grains of Casuarina equisetifolia had only one peak in October (Figure 5v). In the same way, there were notable variations in the period of maximum abundance of Milicia excelsa and Hymenocardia acida pollen grains (Figures 8xviii and 8xix).

Similarly, there were also noticeable variations in the quantity and quality of pollen grains recorded across the study locations. Possibly, differences in the density and distribution of the pollen-producing plants over the study areas may be one of the primary factors that contributed to the observed variations in pollen abundance. The pattern of pollen grains distribution across the locations is exemplified by the diagrams of pollen concentration of common plant sources shown in Figures 11 through 14 . Also, the quantitative variations in monthly occurrence of pollen grains at each location are shown in Figures 4 to 10 . While the monthly quantitative abundance of pollen grains at each location is highlighted in Figures 11 to 14 , whereas the monthly pollen variation in the study locations is highlighted in Figures 15 to 19. Similar findings on the airborne pollen flora of Jabulur- the Central India were previously reported [28-29]. 


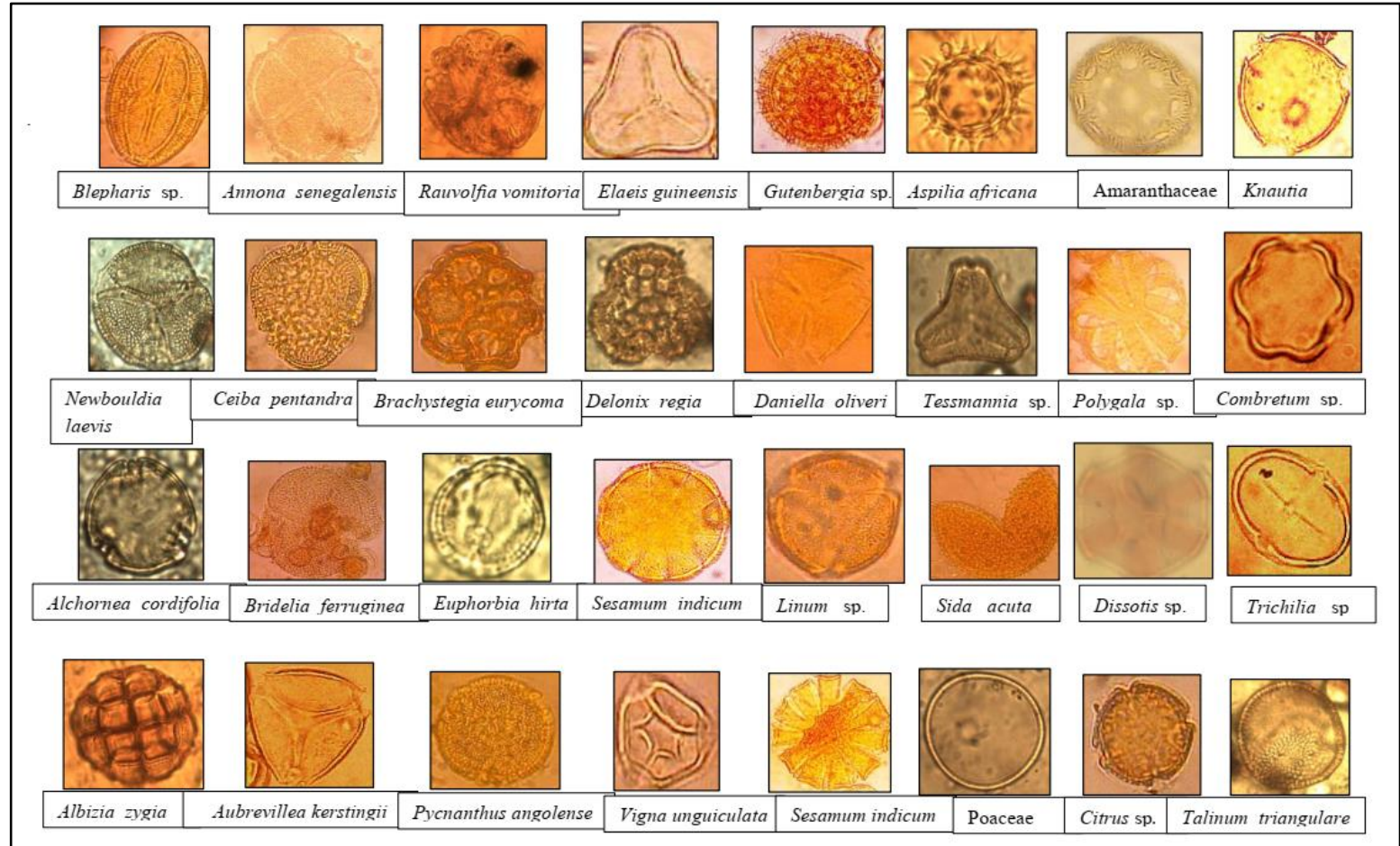

Fig-3: Photomicrograph of some selected pollen grains

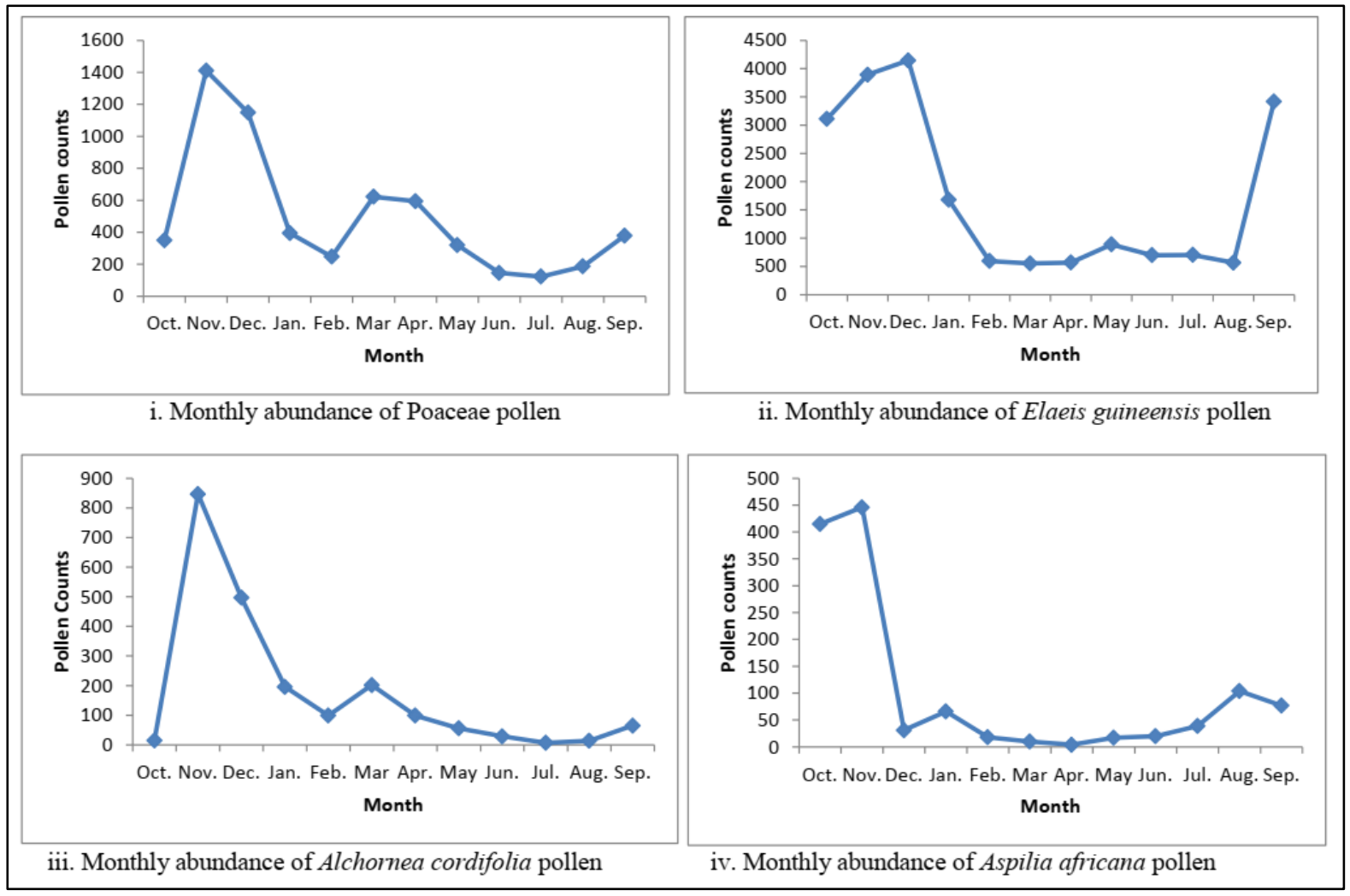

Fig-4: Monthly abundance of pollen of (i) Poaceae (ii) Elaeis guineensis (iii) Alchornea cordifolia (iv) Aspilia Africana 


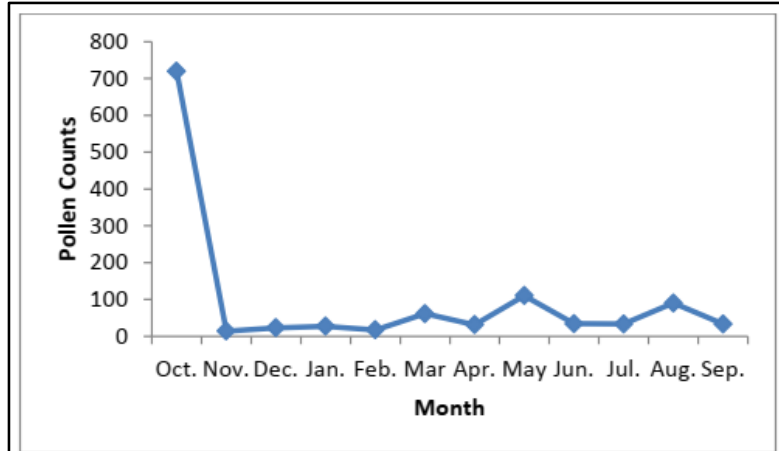

v. Monthly abundance of Casuarina equisetilifolia pollen

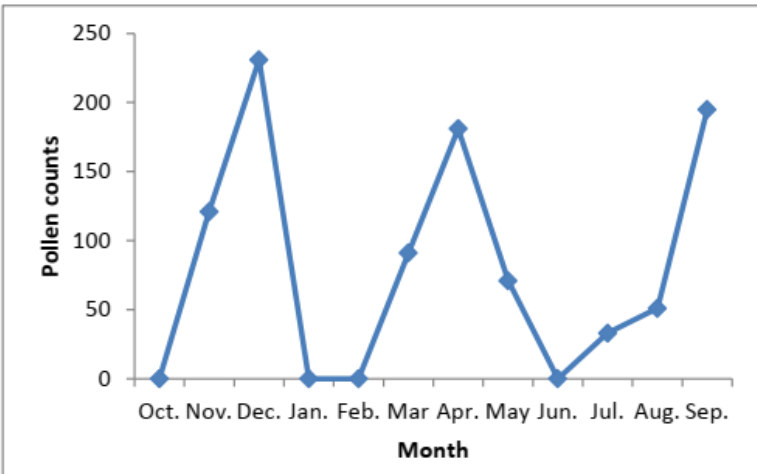

vii. Monthly abundance of Lannea acida pollen

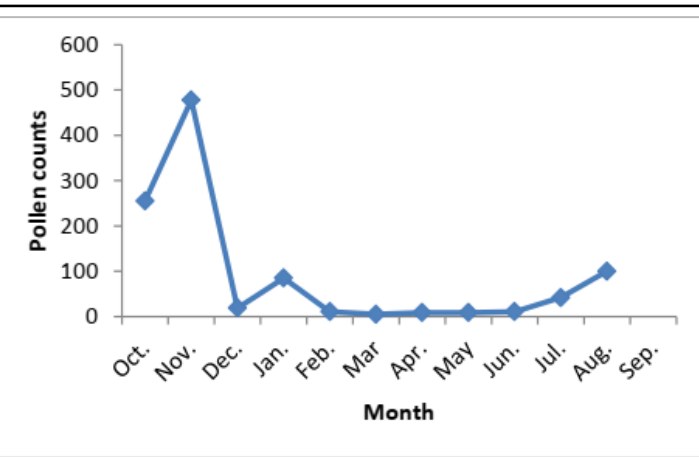

vi. Monthly abundance of Tridax procumbens pollen

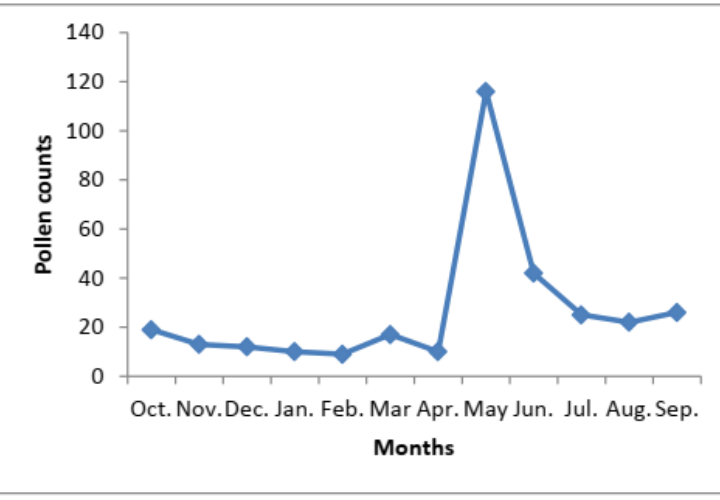

viii. Monthly abundance of Cyperaceae pollen

Fig-5: Monthly abundance of pollen of (v) Casuarina equisetilifolia (vi) Tridax procumbens (vii) Lannea acida (viii) Cyperaceae
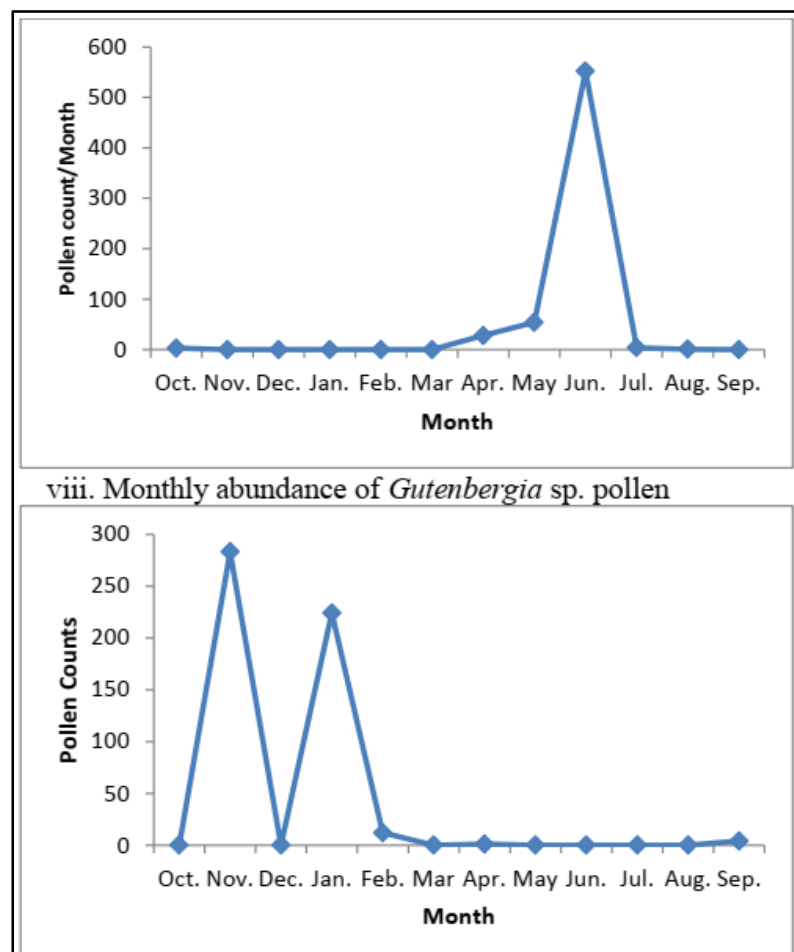

x. Monthly abundance of Periploca sp. pollen

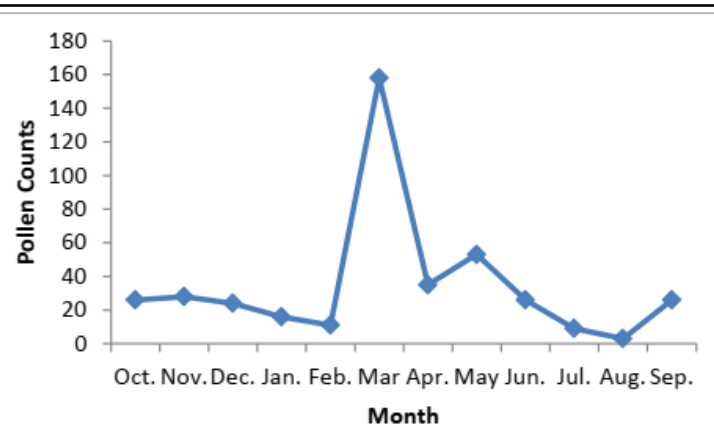

ix. Monthly abundance of Amaranthaceae/ Chenopodiaceae

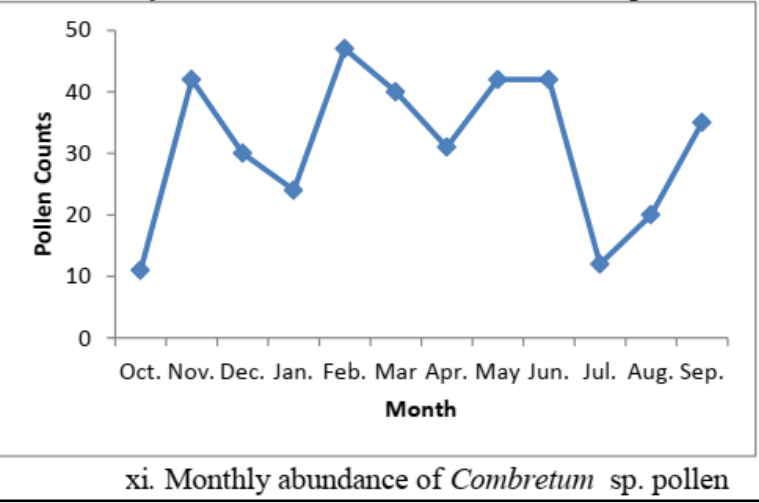

Fig-6: Monthly abundance of pollen of (viii) Gutenbergia sp. (ix) Amaranthaceae/Chenopodiaceae (x) Periploca sp. (xi) Combretum sp 


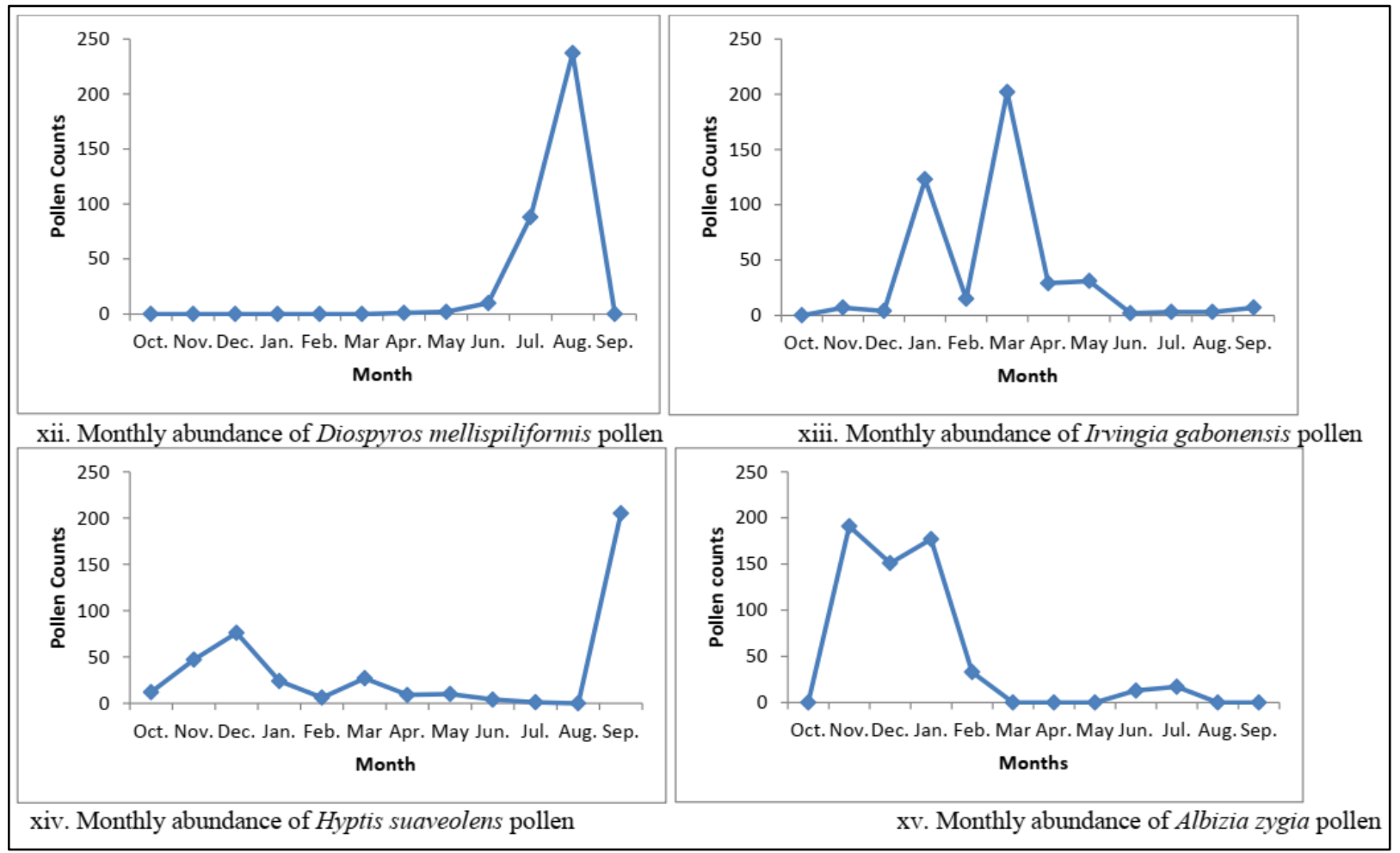

Fig-7: Monthly abundance of pollen (xii) Diospyros mellispiliformis (xiii) Irvingia gabonensis (xiv) Hyptis suaveolens (xv) Albizia zygia
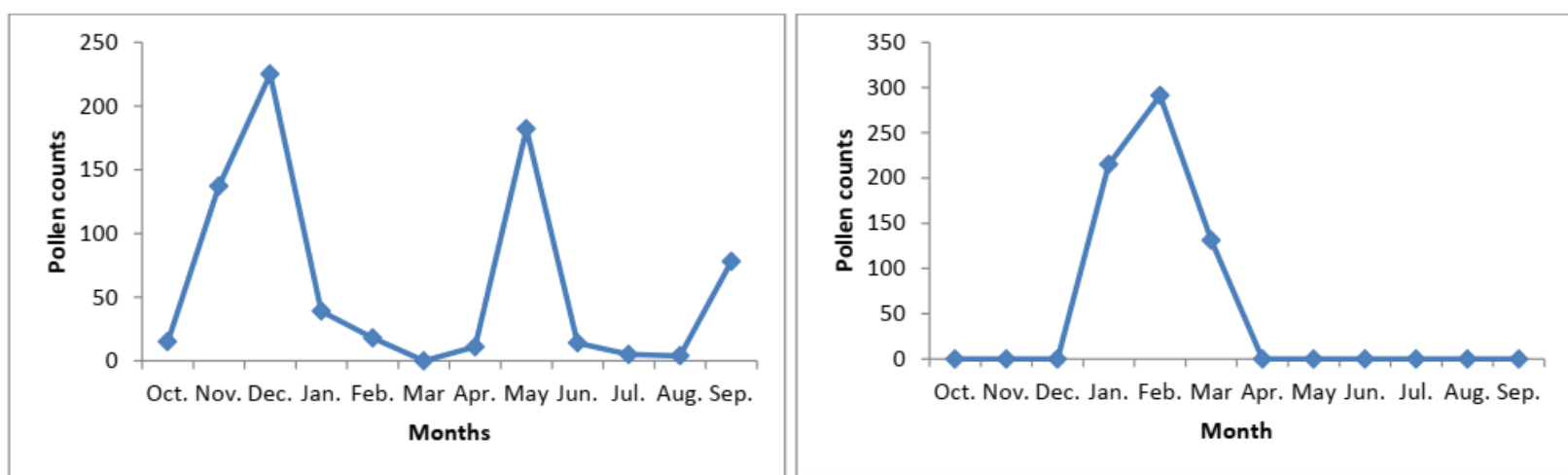

xvi. Monthly abundance of Parkia biglobosa pollen

xvii. Monthly abundance of Prosopis africana pollen

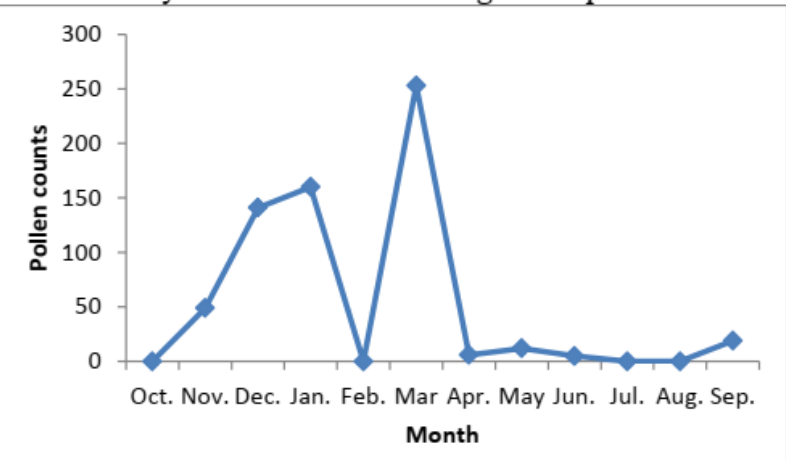

xviii. Monthly abundance of Milicia excelsa pollen

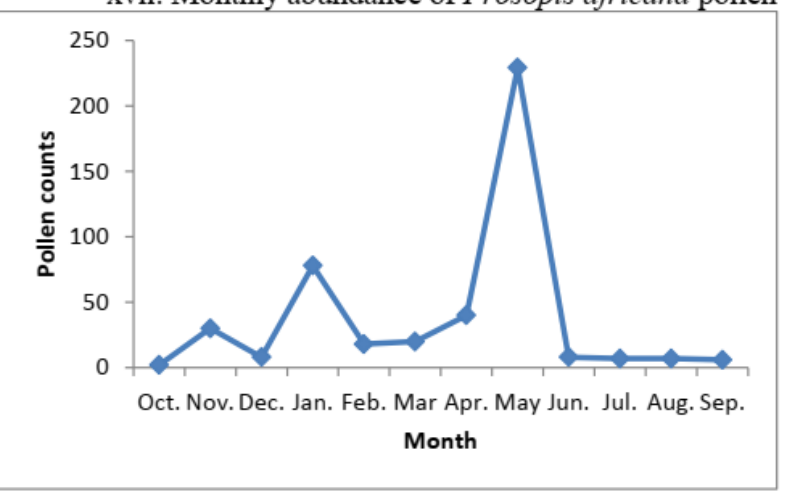

xix. Monthly abundance of Hymenocardia acida pollen

Fig-8: Monthly abundance of pollen of (xvi) Parkia biglobosa (xvii) Prosopis africana (xviii) Milicia excels (xix) Hymenocardia acida 


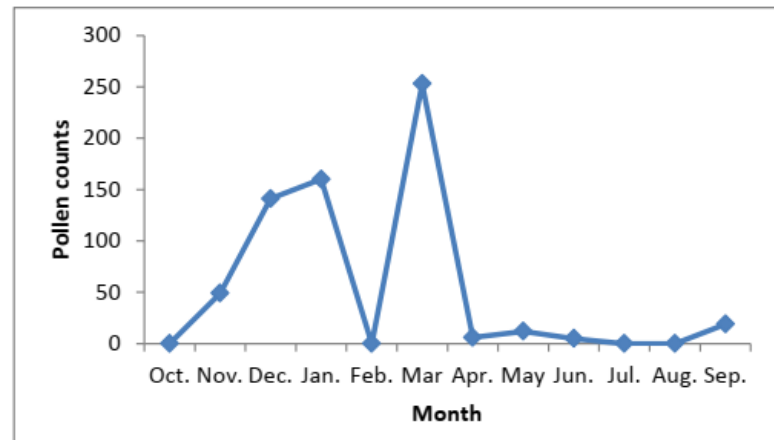

$\mathrm{xx}$. Monthly abundance of Morelia senegalensis pollen

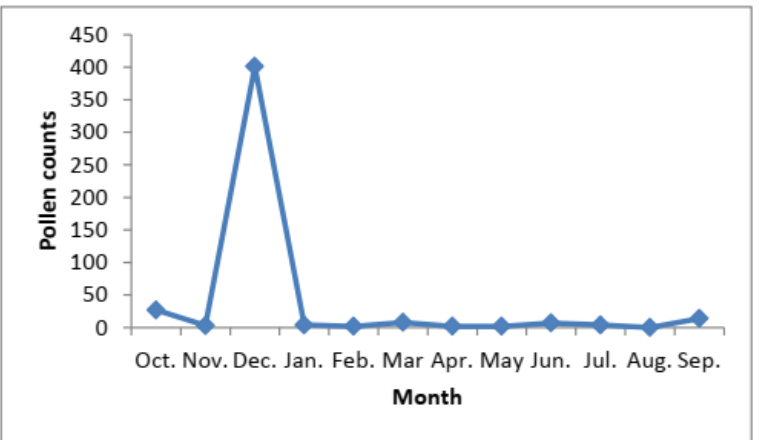

xxii. Monthly abundance of Solanum melongena pollen
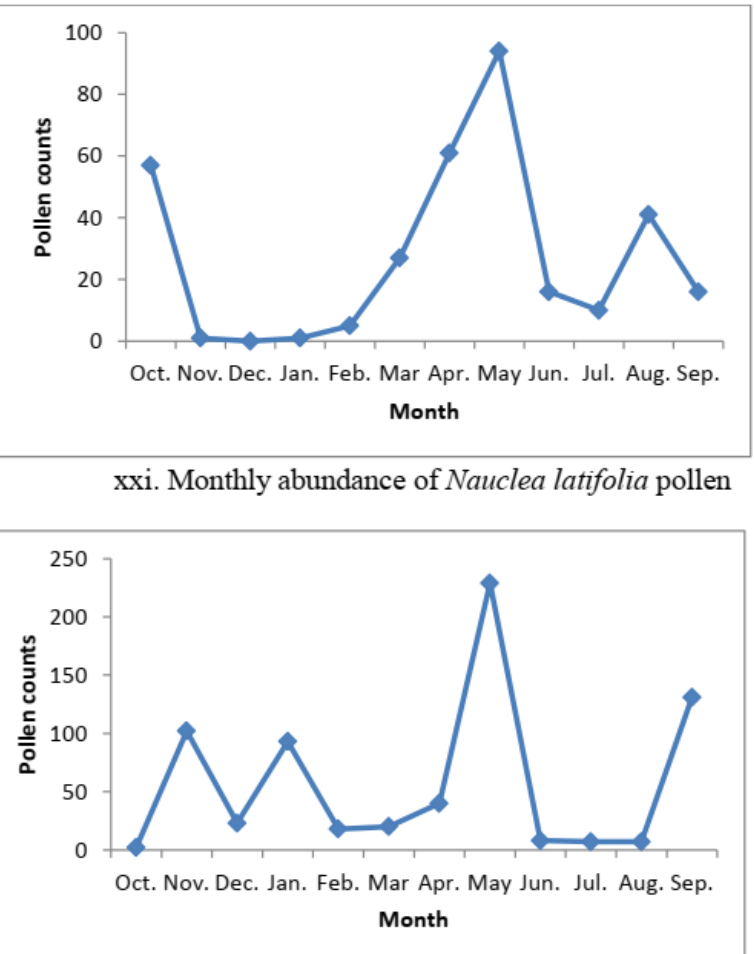

xxiii. Monthly abundance of Triplochiton scleroxylon pollen

Fig-9: Monthly abundance of pollen (xx) Morelia senegalensis (xxi) Nauclea latifolia (xxii) Solanum melongena (xxiii) Triplochiton scleroxylon

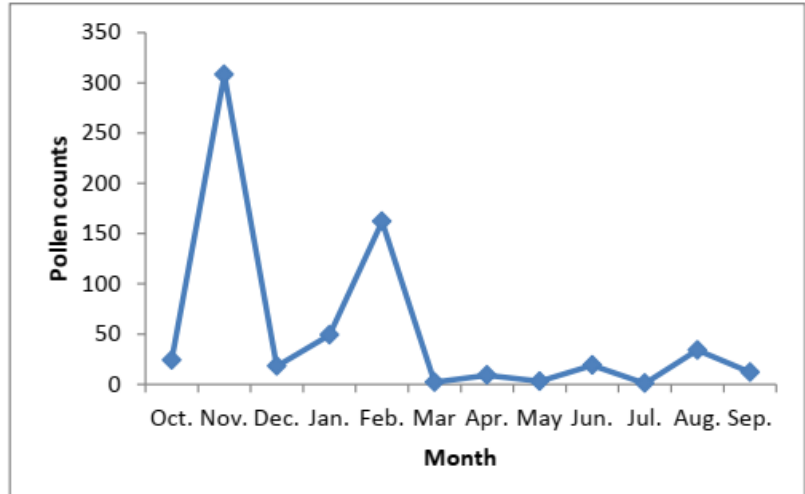

xxiv. Monthly abundance of Sida acuta pollen

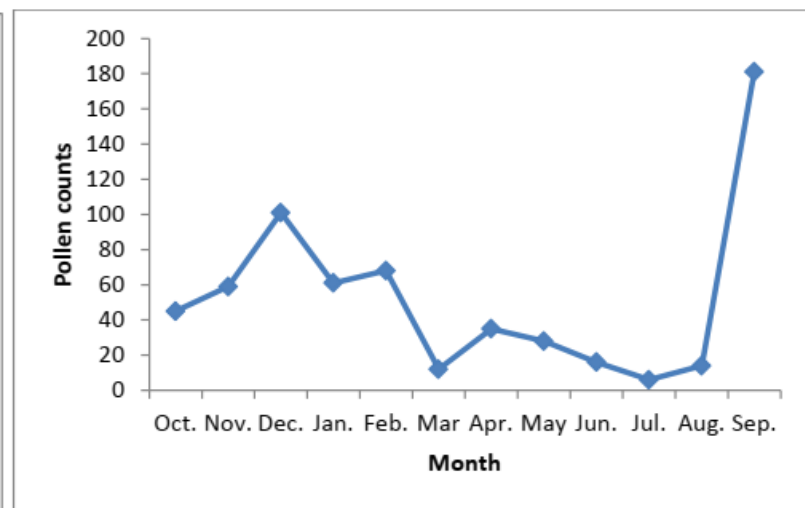

$\mathrm{xxv}$. Monthly abundance of Senna occidentale pollen

Fig-10: Monthly abundance of pollen (x) Sida acuta (y) Senna occidentale

\section{CONCLUSION}

The result of this study gives information on diurnal, seasonal and annual variations in the pollen types and their concentration in the air. A characteristic feature of pollen allergy is its seasonal occurrence associated with the prevalence of pollen of that particular species in the atmosphere. Information generated from this study on the pollen content in the air of the studied environment is necessary in order to forecast pollen incidence. Studies of this nature are useful in finding areas and periods that are comparatively safe for allergic patients. Adequate environmental monitoring through continuous pollen rain analysis and avoidance of exposure to allergic pollen types during their season of prevalence are recommended for safety health and environmental sustainability.

\section{Disclosure of conflict of interest}

The authors declare that there is no conflict of interest.

\section{Acknowledgements}

The co-author is grateful to the Almighty God for life, protection and inspirations; his academic father and supervisor Professor Olugbenga Ebenezer Ige for his generosity and invaluable commitment to this research. My massive thanks go to him for his deep interest in me, scrutiny and painstaking commitment to this research work. 


\section{REFERENCES}

1. Ige, O.E., \& Essien, B.C. (2019). Comparative Study of Dominant Aeropollen and Allergy-Related Cases in Akoko Environment, Ondo State, Nigeria. European Journal of Medical and Health Sciences, 1(2), 1-8.

2. Main, C. E. (2003). Aerobiological, ecological, and health linkages. Environment international, 29(2-3), 347-349.

3. Moore, P. D., \& Webb, J. A. (1978). Illustrated guide to pollen analysis. Hodder and Stoughton.

4. Sivaram, P. (2013). Pollen morphology of selected bee forage plants. Global Journal of Bio-Science and Biotechnology, 2(01), 82-90.

5. Knox, R. B. (2005). Pollen biotechnology for crop production and improvement. Cambridge University Press.

6. Paul, E., Essien, B. C., Idachaba, S. O., Edegbo, E., \& Tamenku, M. M. (2014). Comparative Study of Pollen Morphology of some members of Euphorbiaceae family. Standard Research Journal of Agricultural Sciences, 2(4), 054-058.

7. Essien, B. C., \& Agwu, C. O. C. (2013). Aeropalynological study of Anyigba, Kogi State, Nigeria. Standard Scientific Research and Essays, 1(13), 347-351.

8. Ige, O.E., \& Essien, B.C. (2019). Comparative Study of Dominant Aeropollen and Allergy-Related Cases in Akoko Environment, Ondo State, Nigeria. European Journal of Medical and Health Sciences, 1(2), 1-8.

9. Agwu, C. O. (2001). A study of Niger Delta environment through airborne palynomorphs, Port Harcourt, Nigeria. Palaeoecol Africa, 27, 191-205.

10. Gregory, P. H. (1978). Distribution of airborne pollen and spores and their long distance transport. Pure and Applied Geophysics, 116(2-3), 309-315.

11. Jato, V., Méndez, J., Rodríguez-Rajo, J., \& Seijo, C. (2002). The relationship between the flowering phenophase and airborne pollen of Betula in Galicia (NW Spain). Aerobiologia, 18(1), 55-64.

12. Essien, B. C. (2014). A comparative analytical study of airborne pollen grains, spores and other palynomorphs within Grimard Catholic Hospital, Anyigba, Kogi State, Nigeria. Scholarly J Sci Res Essay (SJSRE), 3(5), 56-60.

13. Agwu, C. O. C., \& Osibe, E. E. (1992). Airborne palynomorphs of Nsukka during the months of February-April, 1990. Nigerian Journal of Botany, 5, 177-185.

14. Melia, M. B. (1984). The distribution and relationship between palynomorphs in aerosols and deep-sea sediments off the coast of Northwest Africa. Marine Geology, 58(3-4), 345-371.

15. Moss, P. T., Kershaw, A. P., \& Grindrod, J. (2005). Pollen transport and deposition in riverine and marine environments within the humid tropics of northeastern Australia. Review of Palaeobotany and Palynology, 134(1-2), 55-69.

16. Njokuocha, R. C., \& Agwu, C. O. C. (2007). Airborne fungal spores in Nsukka municipality. Nig. J. Bot, 20, 349-359.

17. Davies, A. L., \& Bunting, M. J. (2010). Applications of palaeoecology in conservation. The Open Ecology Journal, 3(1).

18. Patton MQ. (1990). Quantitative evaluation and research methods, Second edition. Sage Publications, Newbury Park, CA, 1 523.

19. Tauber H. A static non-overload pollen collector. New Phytologist. 1974 Mar;73(2):359-69.

20. Tauber, H. (1977). Investigations of aerial pollen transport in a forested area [Gribskov, Sealand, Denmark]. Dansk Botanisk Arkiv (Denmark).

21. Pardoe, H. S., Giesecke, T., van der Knaap, W. O., Svitavská-Svobodová, H., Kvavadze, E. V., Panajiotidis, S., ... \& Latałowa, M. (2010). Comparing pollen spectra from modified Tauber traps and moss samples: examples from a selection of woodlands across Europe. Vegetation History and Archaeobotany, 19(4), 271-283.

22. Giesecke, T., Fontana, S. L., van der Knaap, W. O., Pardoe, H. S., \& Pidek, I. A. (2010). From early pollen trapping experiments to the Pollen Monitoring Programme. Vegetation History and Archaeobotany, 19(4), 247-258.

23. Erdtman, G. (1969). Handbook of palynology: Morphology, taxonomy, ecology. An introduction to the study of pollen grains and spores. Hafner.

24. Agwu, C. O. C., \& Akanbi, T. O. (1985). palynological study of honey from four vegetation zones of Nigeria. Pollen et spores, 27, 335-348.

25. Bonnefille, R \& Riollet ,G. (1980). Pollen des savanna d'Afrique orientale. Anatole Press, Paris, France, 1- 140.

26. Sowunmi, M.A. (1995). Pollen of Nigerian plants II. Grana, 34,120 -141.

27. Latorre, F., \& Belmonte, J. (2004). Temporal and spatial distribution of atmospheric Poaceae pollen in Catalonia (NE Spain) in 1996-2001. Grana, 43(3), 156-163.

28. Al-Eisawi, D., \& Dajani, B. (1988). Airborne pollen of Jordan. Grana, 27(3), 219-227.

29. Mishra, R. P., Singh, B., \& Oommachan, M. (2002). Airborne pollen flora of Jabalur-the central India. Aerobiologia, 18(1), 73-81. 